\title{
The alien flora of Sudan and South Sudan: taxonomic and biogeographical composition
}

\author{
Ali Omer (D) - Maha Kordofani · Haytham H. Gibreel • Petr Pyšek • \\ Mark van Kleunen
}

Received: 17 December 2020/ Accepted: 21 February 2021/Published online: 19 March 2021

(C) The Author(s) 2021

\begin{abstract}
Studies on plant invasions depend on local and regional checklists of the alien flora. However, global overview studies have shown that some regions, including many African countries, remain understudied in this regard. To contribute to filling this gap, here we present the first checklist of alien plants of Sudan and South Sudan (the Sudans). We analysed the taxonomic and geographical composition of the species on this list. Our result show that of the 113 alien species in Sudans (99 in Sudan and 59 in South
\end{abstract}

Supplementary Information The online version contains supplementary material available at https://doi.org/10.1007/ s10530-021-02495-7.

A. Omer $(\varangle) \cdot$ M. van Kleunen

Ecology, Department of Biology, University of Konstanz, Universitätsstraße 10, 78464 Konstanz, Germany

e-mail: Ali.omer@uni-konstanz.de

A. Omer · H. H. Gibreel

Department of Forest Management, Faculty of Forestry, University of Khartoum, North Khartoum 13314, Sudan

M. Kordofani

Department of Botany, Faculty of Science, University of Khartoum, Khartoum, Sudan

P. Pyšek

Institute of Botany, Department of Invasion Ecology, Czech Academy of Sciences, 25243 Průhonice, Czech Republic
Sudan), 92 (81.4\%) are naturalized and $21(18.6 \%)$ are just casual aliens. The number of naturalized species represent 2.2\% of the total flora of the Sudans (4096). The alien species belong to 44 families and 85 genera, and many of them are native to Southern America and Northern America (85.8\%). Annual and perennial herbs are the prevailing life forms in the alien flora of the Sudans (68.1\%), and, among the casual species, perennial herbs are underrepresented whereas woody tree species are over-represented. Alien plants of the Sudans are mostly used for medicinal and environmental purposes globally. The naturalized plants predominantly occur in man-made disturbed habitats,

\footnotetext{
P. Pyšek

Department of Ecology, Faculty of Science, Charles

University, Viničná 7, 12844 Prague, Czech Republic

M. van Kleunen

Zhejiang Provincial Key Laboratory of Plant Evolutionary

Ecology and Conservation, Taizhou University,

Taizhou 318000, China
} 
such as agricultural and ruderal habitats. This first overview of the alien flora of the Sudans should stimulate further research and recording of the alien flora to better understand the drivers and consequences of alien plants in the Sudans.

Keywords Exotic plants $\cdot$ Non-native flora $\cdot$ Native origins · Naturalization · Sudan · South Sudan · Plant characteristics

\section{Introduction}

The introduction and subsequent establishment of alien plant species outside their native ranges is among the main drivers of ecosystem and biodiversity changes globally (Pyšek et al. 2020, 2012; Vilà and Hulme 2017). In developing countries, especially in Africa, alien plants are recognized as one of the major threats to agricultural production and food security (Pratt et al. 2017; Richardson et al. 2020). Globally, there are now more than 13,000 alien plant species that have managed to establish wild populations (i.e. have become naturalized, Blackburn et al. 2011; Richardson et al. 2000) outside their native ranges (van Kleunen et al. 2015). The numbers are still increasing (Seebens et al. 2017), and this trend is predicted to continue (Seebens et al. 2021). This alarming situation has stimulated studies that focus on drivers and consequences, i.e. impacts, of plant invasions. Such studies heavily rely on investigations of local, regional and global alien floras (Ansong et al. 2019; Baard and Kraaij 2014; Inderjit et al. 2018; Khuroo et al. 2012; Lambdon et al. 2008; van Kleunen et al. 2015). Therefore, it is vital to make regional checklists of alien floras that are as comprehensive and accurate as possible (Pyšek et al. 2017a).

A major effort to identify and document alien plant species all over the globe resulted in the Global Naturalized Alien Flora (GloNAF) database (van Kleunen et al. 2019). GloNAF is a global database of regional inventories of naturalized and invasive plant species. However, while some regions (e.g. Europe and America) are intensively researched, others, particularly in Africa (with the exception of Southern Africa), are understudied (Pyšek et al. 2008; van Kleunen et al. 2019). This imbalance might bias analyses of global patterns, and constrain our knowledge of specific invasion mechanisms in the understudied regions. Therefore, increasing the completeness of our knowledge on the occurrences and distributions of alien plant species is essential to achieve a more comprehensive picture of biological invasions, and to study their drivers and consequences.

Some studies on alien plant inventories have been carried out in African countries, including among others South Africa (Musil et al. 2007; van Wilgen et al. 2020), Northwestern Kenya (Stadler et al. 2008), Ghana (Ansong et al. 2019), Egypt (El-Beheiry et al. 2020) and Algeria (Meddour et al. 2020). Nonetheless, there is still a lack of reliable data on plant invasions in most African countries. To contribute to filling this knowledge gap, we present the first inventory of the alien flora of Sudan and South Sudan (hereafter 'the Sudans'). Specifically, we aimed to (i) identify the stage that alien plant species reached in the invasion process (i.e. casual and naturalized), using the definitions proposed by Richardson et al. (2000), (ii) analyse taxonomic, geographical and ecological patterns in the alien flora, and (iii) analyse whether the casual and naturalized alien species differ in their species characteristics in the Sudans.

\section{Methods}

Study area

The Sudans (i.e. Sudan and South Sudan) were until 2011 one country, called Sudan. Then, after decades of civil war, the southern part became the world's newest nation, South Sudan. Most studies on the Sudanese flora were done before the separation of the Sudans (Darbyshire et al. 2015). Therefore, to provide a wider overview of the alien flora of the Sudans, we consider both countries here jointly. The former Sudan, which was an Anglo-Egyptian condominium from 1899 until 1956 (Metz 1991), used to be the largest African country, covering an area of $2,505,825 \mathrm{~km}^{2}$, and lies between $3.6^{\circ}$ and $22^{\circ} \mathrm{N}$ latitude, and $21.8^{\circ}$ and $38.6^{\circ} \mathrm{E}$ longitude. The Sudanese landscape features flatlands and some hills (e.g. the Red Sea Hills and Nuba Mountains). Its environment varies considerably from the north, with mostly sandy soils and very low rainfall, to the south, with clay soils and relatively high and reliable rainfall up to $1300 \mathrm{~mm}$ annually. Temperatures are typically high throughout the year and daytime temperatures can frequently exceed $40{ }^{\circ} \mathrm{C}$. In botanical 
terms, the Sudans are very rich and diverse regions with 4096 taxa of which $2 \%$ are endemic. Following Darbyshire et al. (2015), we divided the Sudans into nine geographical regions that capture most of the phytogeographical variation (Fig. 1 and Table 1).

Compilation of the alien flora data

The list of alien plant species occurring in the Sudans is based on the most recent and comprehensive book on their floras (The Plants of Sudan and South Sudan: an Annotated Checklist. Darbyshire et al. 2015). The aim of this book was to provide an extensive documentation of the native and alien seed plant species (i.e. angiosperms and gymnosperms) that occur in the Sudans. The list of 4096 taxa was compiled from literature, web-based data sources and herbarium records from the Sudans in the Kew herbarium and Natural History Museum of London (United Kingdom), the University of Khartoum

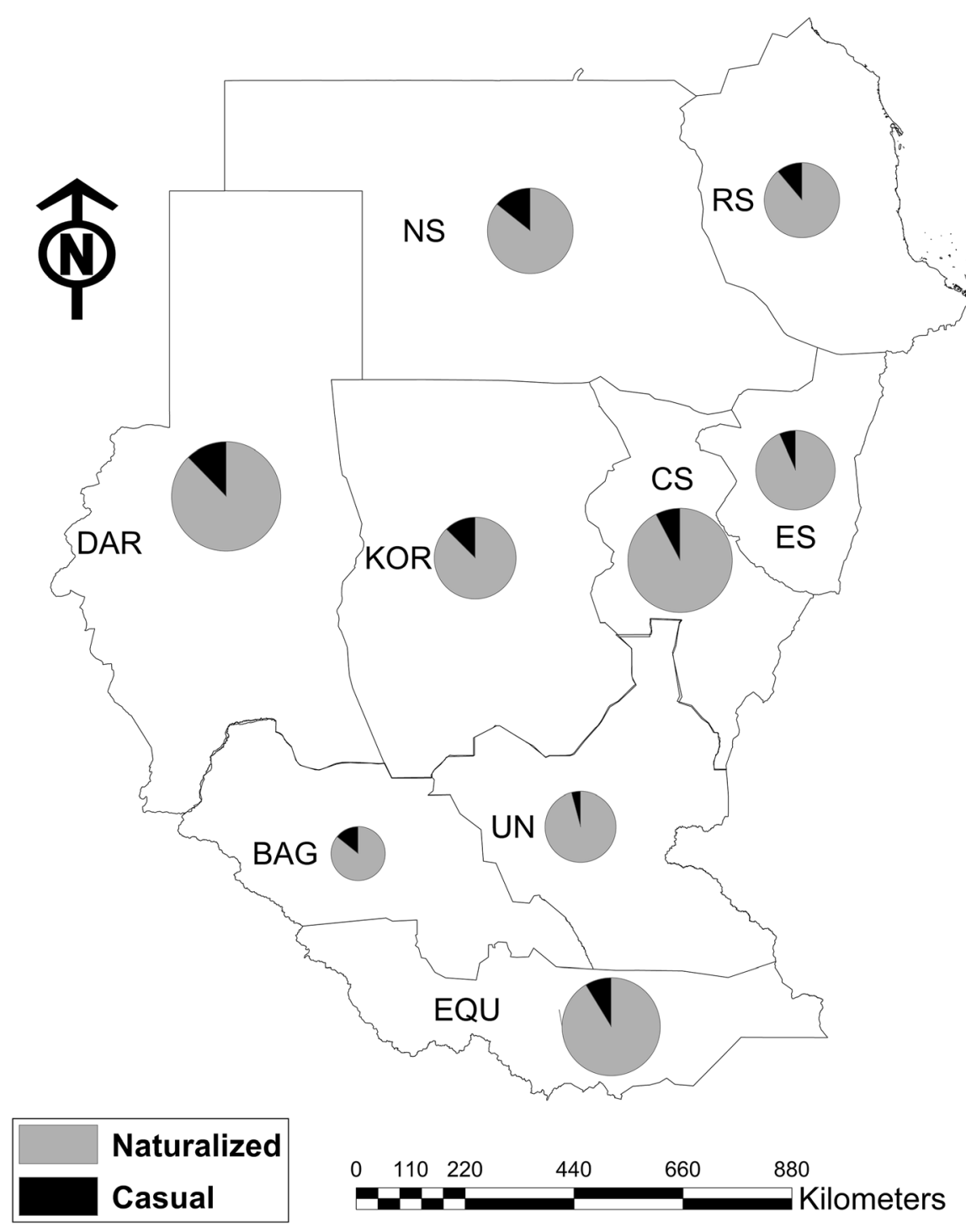

Fig. 1 Map of the Sudans subdivided into nine regions following (Darbyshire et al. 2015); the northern six regions are in Sudan (NS, RS, DAR, KOR, CS and ES) and the southern three regions are in South Sudan (BAG, UN and EQU). For full names of the regions, see Table 1 . Pie charts show the invasionstatus composition of alien plant in each region, and their sizes are proportional to the total number of alien species in the region 
Table 1 The nine geographical regions of the Sudans, with information on the numbers of casual and naturalized alien species, area, number of native species, and human population density

\begin{tabular}{|c|c|c|c|c|c|c|}
\hline \multirow[t]{2}{*}{ Region } & \multirow[t]{2}{*}{ Country } & \multicolumn{2}{|c|}{ Alien species numbers } & \multirow{2}{*}{$\begin{array}{l}\text { Area } \\
\left(\mathrm{km}^{2}\right)\end{array}$} & \multirow{2}{*}{$\begin{array}{l}\text { No. of } \\
\text { Native } \\
\text { species }\end{array}$} & \multirow{2}{*}{$\begin{array}{l}\text { Population } \\
\text { density } \\
\left(\text { per } \mathrm{km}^{2}\right)\end{array}$} \\
\hline & & Casuals & Naturalized & & & \\
\hline $\begin{array}{l}\text { Central Sudan (Khartoum, Blue Nile, } \\
\text { White Nile and Sinnar) }\end{array}$ & Sudan & 4 & 48 & 159,614 & 714 & 116.6 \\
\hline Darfur states & Sudan & 7 & 50 & 504,000 & 1124 & 18.7 \\
\hline $\begin{array}{l}\text { Eastern Sudan } \\
\text { (Kassala and Al Qadarf) }\end{array}$ & Sudan & 2 & 28 & 111,973 & 426 & 42.2 \\
\hline Kurdofan states & Sudan & 4 & 28 & 376,145 & 758 & 14 \\
\hline $\begin{array}{l}\text { Northern } \\
\text { (Ash Shamaliyah, River Nile and Nahr } \\
\text { an Nil) }\end{array}$ & Sudan & 5 & 30 & 470,888 & 317 & 5.2 \\
\hline Red Sea & Sudan & 3 & 24 & 218,887 & 775 & 6.7 \\
\hline $\begin{array}{l}\text { Bahr el Ghazal } \\
\text { (Northern Bahr el Ghazal, Western } \\
\text { Bahr el Ghaza, Warrap and Lakes) }\end{array}$ & S. Sudan & 2 & 12 & 210,780 & 2451 & 18.6 \\
\hline $\begin{array}{l}\text { Equatoria } \\
\text { (Western Equatoria, Central Equatoria, } \\
\text { and Eastern Equatoria) }\end{array}$ & S. Sudan & 6 & 42 & 195,848 & 902 & 19.2 \\
\hline $\begin{array}{l}\text { Greater Upper Nile } \\
\text { (Upper Nile, Unity and Jonglei) }\end{array}$ & S. Sudan & 1 & 23 & 237,701 & 704 & 17.4 \\
\hline
\end{tabular}

herbarium (Sudan), the University of Cairo herbarium (Egypt) and the East African Herbarium (Kenya) (Darbyshire et al. 2015). For the alien species, the book provides information about the accepted taxonomic names, life forms, native origins, distribution within the Sudans, status (i.e. cultivated, alien, weed, naturalized, and invasive), and the year of the first record in the Sudans.

Alien plant taxa are defined as those taxa in a given area whose presence there is due to intentional or accidental introduction by humans (synonyms: exotic plants, non-native plants, nonindigenous plants; Richardson et al. (2000). For the list of alien plant species in the Sudans, we followed a conservative approach, and included only the taxa for which there is a strong agreement among botanical experts that they are alien to the countries. The initial list included 197 species (163 in Sudan and 105 in South Sudan). This list was validated by botanical experts of the Faculty of Science and the Faculty of Forest of the University of Khartoum (Sudan), including some people that had been part of the project "The Plants of Sudan and South Sudan" (Darbyshire et al. 2015). After this validation, the list was reduced to 179 alien species.

\section{Classification of invasion status}

As stated above, the book on the flora of the Sudans provides information about the invasion status of most of the alien taxa in the Sudans. However, as this information is not provided consistently, we reclassified the invasion status of the introduced taxa using the invasion-stages scheme of (Richardson et al. 2000): (i) cultivated taxa that have been introduced to the Sudans but have not been recorded in the wild yet, (ii) casual aliens, i.e. alien plants that may flourish and even reproduce occasionally in an area, but do not form self-replacing populations, and rely on repeated introductions for their persistence, and (iii) naturalized plants, i.e. alien plants that reproduce consistently in the wild and sustain populations over many life cycles without direct intervention by humans. As probably several thousands of alien species are being cultivated in the Sudans, like in the neighboring Egypt (Ammar 2020), our list of cultivated alien taxa is very incomplete. The cultivated alien species listed in Darbyshire et al. (2015), however, are likely to represent some of the most common cultivated plants in the Sudans. As knowledge on such non-naturalized 
species can be important for comparative studies (van Kleunen et al. 2010a), we included the cultivated alien plants (66 species) in our alien inventory (Supplemental Information 4). However, as they are not yet found in the wild, we excluded them from our analyses. We did not classify the naturalized species as being invasive or not, because we do not have data on their spread rates and impacts. However, the tree species Prosopis glandulosa and Prosopis juliflora are considered to be highly invasive in the Sudans especially in Eastern and Northern Sudan. For our analyses, we kept 113 species for which the invasion category (i.e. casual and naturalized) is known (Supplemental Information 2) and excluded the species for which the naturalization status in unknown (19 species, Supplemental Information 3) and the species that are only found in cultivation (66 species, Supplemental Information 4).

Origins, introduction histories, economic uses, naturalization extent and life forms of alien species

To harmonize species names between the checklist of alien plants of the Sudans and the species lists of other datasets (see below), we standardized the taxonomic names according to The Plant List (version 1.1; http:// www.theplantlist.org); with the $\mathrm{R}$ package Taxonstand (Cayuela et al. 2019).

Darbyshire et al. (2015) provides information about the regions of origin of each species. However, as this information may not be complete, and to assure consistency between this checklist and other global databases used in this study, we collected additional native origin data from the Germplasm Resources Information Network (GRIN 2019, https://npgsweb. ars-grin.gov/), the World Checklist of Selected Plant Families (WCSP; http://wcsp.science.kew.org/) and the Plant of the World Online database (POWO; http:// www.plantsoftheworldonline.org/). We assigned each species to its continent(s) of origin, using the continental scheme of the Taxonomic Databases Working Group (i.e. the nine TDWG-1 regions). We also used the same data sources to extract the number of TDWG level-2 regions (total number is 52) each alien species is native to as an estimate of its native range size (see also, Maurel et al. 2016; Razanajatovo et al. 2016). Furthermore, we extracted data on each species' global naturalization extent, measured as the number of regions, excluding the Sudans (a total of 1028 regions), where a species is naturalized according to the Global Naturalized Alien Flora (GloNAF) database (van Kleunen et al. 2019).

Exact data on the year of introduction (from which the residence time is derived; e.g. Pyšek and Jarošík 2005) and the reason for introduction of each species is hard to obtain (Rejmánek 2000). Here, we used the year of the first collection provided by (Darbyshire et al. 2015) to calculate minimum residence time as 2020 minus the year of first collection (see also, Ansong et al. 2019; Hamilton et al. 2005; Pyšek et al. 2002; Rejmánek 2000). To get an indication of the potential reason for introduction, we extracted the known economic uses of each alien species from the World Economic Plants (WEP) database (National Plant Germplasm System GRIN-GLOBAL; https:// npgsweb.ars-grin.gov/gringlobal/taxon/

taxonomysearcheco.aspx, accessed 7 Jan 2016). We also collected data on the habitats in which the alien species managed to naturalize in the Sudans according to Darbyshire et al. (2015).

To assess whether casual and naturalized alien species differ in biological traits, we selected traits that have been reported as ecologically relevant and important for naturalization success in earlier studies (Divíšek et al. 2018; Maurel et al. 2016; PintoLedezma et al. 2020; Pyšek and Richardson 2007; van Kleunen et al. 2010b). We extracted data on the life forms from Darbyshire et al. (2015), and verified it using several publications and online databases (Engemann et al. 2016; Kattge et al. 2020; Rice et al. 2019; Taseski et al. 2019; WCSP 2015). As these sources use different life-form schemes, we harmonized them to consider six standard life-form categories: short-lived (annual and biennial) herbs, longlived herbs, climbers, aquatics, shrubs and trees. We found such data for all species. In addition, we extracted data on plant height and seed mass from the TRY database (Kattge et al. 2020) and complemented with data from other sources (see Supplemental Information 1). We found data on plant height for 107 species $(94.6 \%)$ and seed mass for 69 species (61\%). Since missing data would reduce the sample size and might lead to a biased output (Nakagawa 2015), we imputed the missing values for these traits using the $\mathrm{R}$ package "missForest", which is a nonparametric method based on a random forest algorithm (Stekhoven, Bühlmann 2011). We produced 999 imputed data sets. 
Statistical analysis

All analyses and figures were done in R, version 3.6.1 ( $\mathrm{R}$ Core Team 2019), with the exception of the map of Fig. 1, which was created using ArcGIS 10.3.1.

To test whether casual and naturalized alien species differed with regards to the dominant species' growth forms and geographical origins, we analysed the proportions of the different growth forms and of the different origins using row $\times$ column contingency tables of species counts. To assess in which group of species (i.e. casual and naturalized) the counts of species with different growth forms or geographical origins were lower or higher than expected by chance, we used adjusted standardized residuals of G-tests, which were compared to critical values of the normal distribution (e.g. Pyšek et al. 2017b; Vinogradova et al. 2018).

We compared biological traits (i.e. plant height and seed mass), native range size, global naturalization extent and the number of known economic uses of the casual and naturalized species using randomization tests. We used simple randomizations to test whether there are differences in the medians of these variable between the two invasion-status groups $(p<0.05$, two-tailed test; see Divíšek et al. (2018)). In each random draw ( $n=9,999)$, we randomly shuffled the values of the variable between the invasion-status groups. This was done for all the 999 imputed data sets. The observed median was compared to the expected median value of the random draws.

\section{Results}

Alien species in the Sudans

Our analyses below are based on 113 species with known invasion status. Of the 113 alien species in the Sudans, $21(18.6 \%)$ are casuals, and $92(81.4 \%)$ are naturalized (see Supplemental Information 2 for the complete list of species and their distribution in the nine Sudanese regions). In general, more alien species have been recorded in Sudan (99 species: 18 casual and 81 naturalized) than in South Sudan (59 species: 10 casual and 49 naturalized) with 45 (39.8\%) species that occur in both countries. The nine regions of the Sudans showed variation in the total number of alien species with respect to the different invasion
Fig. 2 Alien flora of the Sudans. a Cumulative numbers of all alien species (i.e. casual and naturalized) and the subsets of the naturalized alien species separately in relation to the date of first record in the Sudans. b The numbers of species per major class of economic use see (WEP and van Kleunen et al. 2020). c Percentages of naturalized species in the main habitats of the Sudans

categories (Fig. 1 and Table 1), but we found no significant association between these numbers and geographical, climatic, and socio-economic characteristics of the regions.

The first alien plant species in the Sudans was recorded before the year 1800 (Mangifera indica). From the year 1920, soon after the Anglo-Egyptian condominium of the Sudans in 1899-1956, until the late 1980s, there was a rapid and steady increase in the number of alien species, and this was followed by a period of rather slow and lingering increase until present (Fig. 2a). Only three new species have been recorded after 1990. The same pattern was observed for the subset of naturalized species (Fig. 2a). Concerning economic uses, which are possible reasons for introduction, medicinal uses are prevailing, while fodder and gene sources (e.g. species whose beneficial genes have been used for crop improvement) are the least common uses. This pattern is similar across the different invasion stages (Fig. 2b). Naturalized species inhabit a variety of habitats, but man-made habitats (ruderal habitats and agricultural habitats) hold more of the naturalized species $(60.9 \%)$ than natural habitats (Fig. 2c).

Taxonomic composition of alien flora

The 113 alien species belong to 44 families (Supplemental Information 2), and the Leguminosae (28 species, $24.7 \%$ ), Compositae (10 species, $8.8 \%$ ) and Solanaceae ( 9 species, $7.9 \%$ ) are the families with the largest numbers of alien species in the Sudans (Table 2). These families also have the largest numbers of naturalized species (Table 2). Moreover, the alien species belong to 85 genera of which most are represented by only one or two species. The genera with most alien species are Eucalyptus (6 species) and Euphorbia (6). Two of the alien species occur in all nine regions of the Sudans-Azadirachta indica (naturalized), Corchorus olitorius (naturalized), nine 

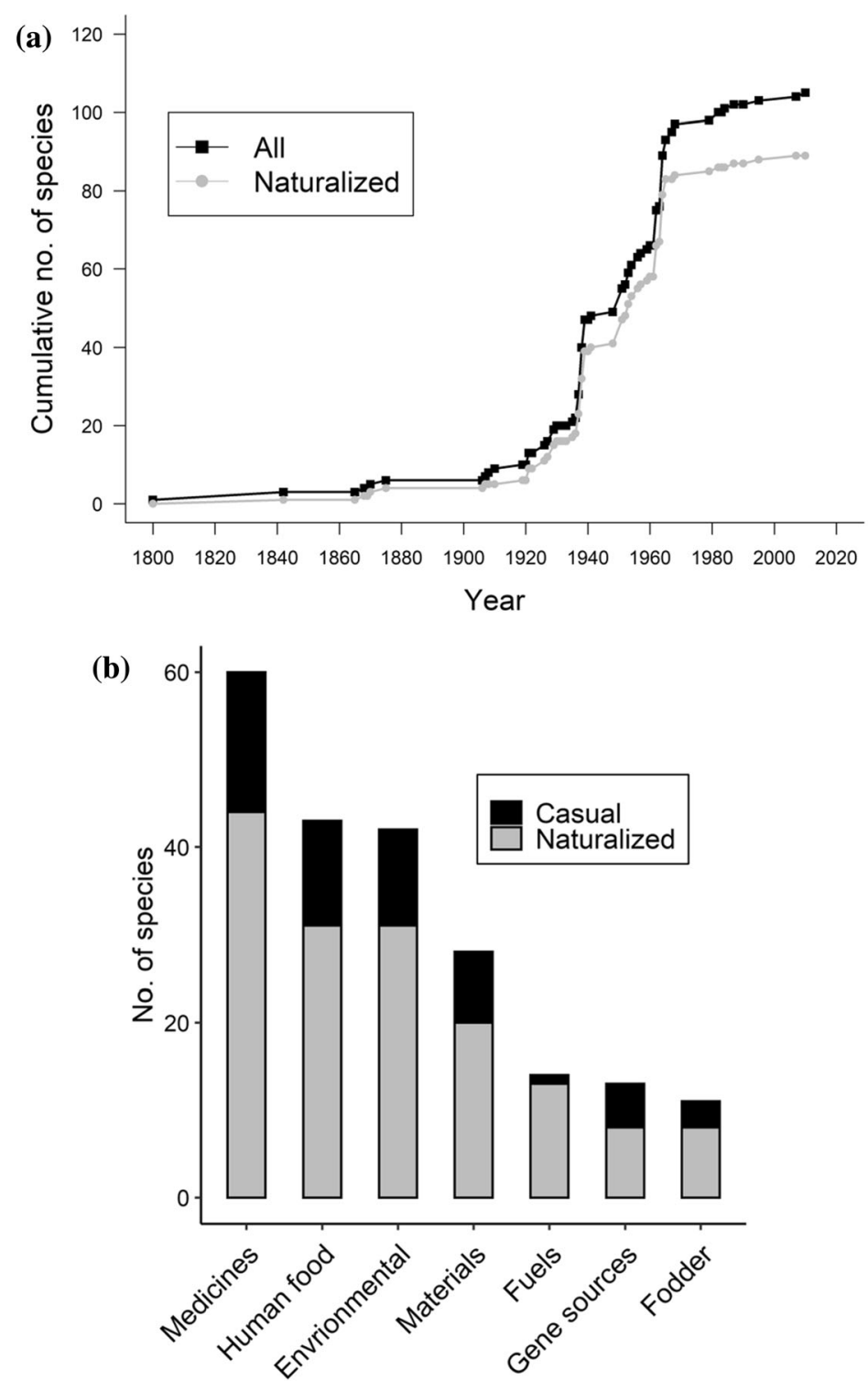

(c) Dry sandy and rocky lands $(3.9 \%)$

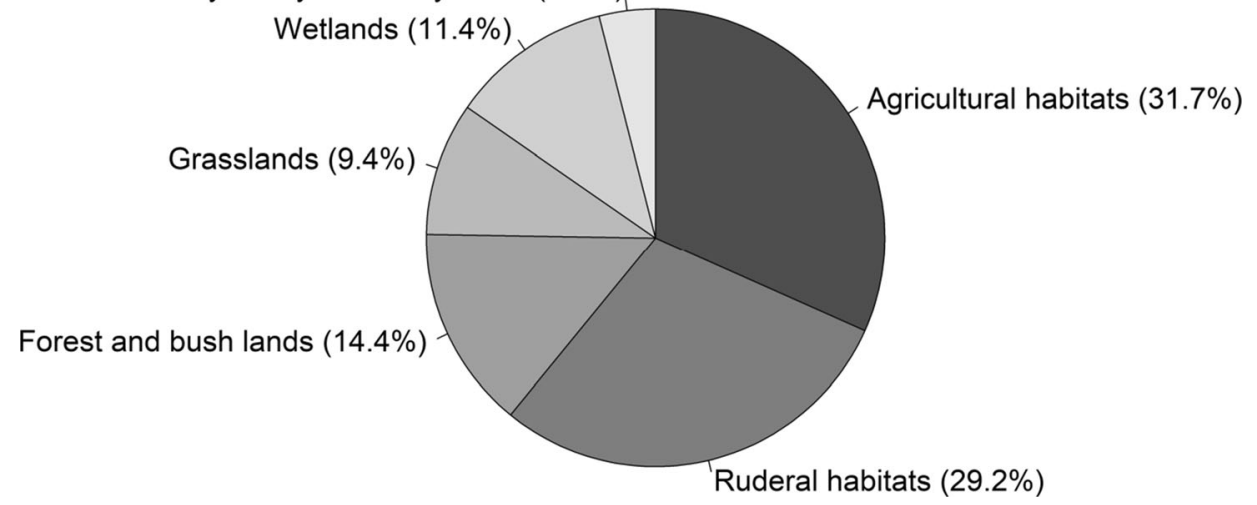


Table 2 The plant families represented by more than one species in the alien flora descending order according to the total number of alien species

For each family, we provide the total number of alien species, separately for Sudan and South Sudan, and the numbers of species in each of the invasion stages (i.e. casual and naturalized) of the Sudans, in

\begin{tabular}{|c|c|c|c|c|c|}
\hline \multirow[t]{2}{*}{ Family } & \multicolumn{3}{|c|}{ All alien species number } & \multicolumn{2}{|l|}{ Status } \\
\hline & Total & Sudan & South Sudan & Casual & Naturalized \\
\hline Leguminosae & 28 & 25 & 9 & 8 & 20 \\
\hline Compositae & 10 & 8 & 6 & & 10 \\
\hline Solanaceae & 9 & 8 & 8 & 1 & 8 \\
\hline Amaranthaceae & 7 & 5 & 7 & & 7 \\
\hline Convolvulaceae & 6 & 4 & 3 & & 6 \\
\hline Cucurbitaceae & 4 & 3 & 3 & 1 & 3 \\
\hline Euphorbiaceae & 3 & 3 & 2 & 1 & 2 \\
\hline Anacardiaceae & 2 & 2 & 1 & 1 & 1 \\
\hline Apiaceae & 2 & 2 & 3 & & 2 \\
\hline Araceae & 2 & 2 & 2 & & 2 \\
\hline Malvaceae & 2 & 2 & 1 & & 2 \\
\hline Moraceae & 2 & 2 & & & 2 \\
\hline Myrtaceae & 2 & 1 & 2 & 2 & \\
\hline Polygonaceae & 2 & 2 & 1 & & 2 \\
\hline Rhamnaceae & 2 & 2 & 1 & & 2 \\
\hline
\end{tabular}

species are found in six to eight regions (Table 3), whereas 34 of the alien species occur in only one Life forms and geographical origin of the alien flora region of the Sudans (Supplemental Information 2).

The most common life form among the alien species of the Sudans are annual herbs (44 species; $38.9 \% ; 7$ casuals, 37 naturalized aliens). The least common life form among the alien species of the Sudans are aquatics with only two species, but both have managed

Table 3 The eleven most widespread alien plant species in the Sudans, in descending order according to the number of Sudanese states in which they occur

\begin{tabular}{lllll}
\hline Species & No. states & Life form & Status & Family \\
\hline Azadirachta indica & 9 & Tree & Naturalized & Meliaceae \\
Corchorus olitorius & 9 & Annual herb & Naturalized & Malvaceae \\
Mangifera indica & 8 & Tree & Casual Anacardiaceae \\
Bougainvillea spectabilis & 8 & Woody perennial vine & Naturalized Nyctaginaceae \\
Phyllanthus maderaspatensis & 7 & Perennial herb & Naturalized & Phyllanthaceae \\
Mimosa pigra & 7 & Shrub & Naturalized & Leguminosae \\
Jatropha curcas & 7 & Shrub & Naturalized & Euphorbiaceae \\
Datura stramonium & 7 & Annual herb & Naturalized & Solanaceae \\
Chrysanthellum indicum subsp. afroamericanum & 7 & Annual herb & Naturalized & Compositae \\
Amaranthus spinosus & 6 & Annual herb & Naturalized & Amaranthaceae \\
Sonchus asper & 6 & Annual or biennial herb & Naturalized Compositae \\
\hline
\end{tabular}

For each species, we provide the number of regions in which they occur, the life forms, the invasion stage (i.e. casual or naturalized), and the family it belongs to 
to naturalize. We found significant differences in the representation of life forms between the two invasion stages $\left(\chi^{2}=11.97 .08, \mathrm{df}=5 ; p<0.035\right)$. Among the casual alien species, perennial herbs and trees are significantly under- and over-represented, $((P=0.040$ and 0.019 , respectively; Fig. 3). Among naturalized species, there was no significant differences in the representation of the different growth forms (Fig. 3).

The most common TDWG continent of origin of alien plants in the Sudans is Southern America (59 species; 52.2\%), followed by Northern America (38 species; 33.6\%; Fig. 4). After Antarctica, which has not donated any species to the Sudans, the Pacific Islands are the least common donor of alien species ( 4 species; 3.5\%; Fig. 4). The pattern is similar for the subset of naturalized species (Fig. 4), and the continents of origin did not differ in their representation between the two invasion stages $\left(\chi^{2}=11.97, \mathrm{df}=11\right.$; $P=0.365)$.

Species characteristics of the three invasion-status groups

Naturalized species in the flora of the Sudans have significantly larger native range sizes than casual aliens $(P=0.016$, Fig. $5 \mathrm{~d})$, and also tend to be naturalized in more regions worldwide (i.e. have a wider global naturalization extent) than casual aliens (marginally significant: $P=0.096$, Fig. 5e). However, we did not find any differences in seed mass, plant

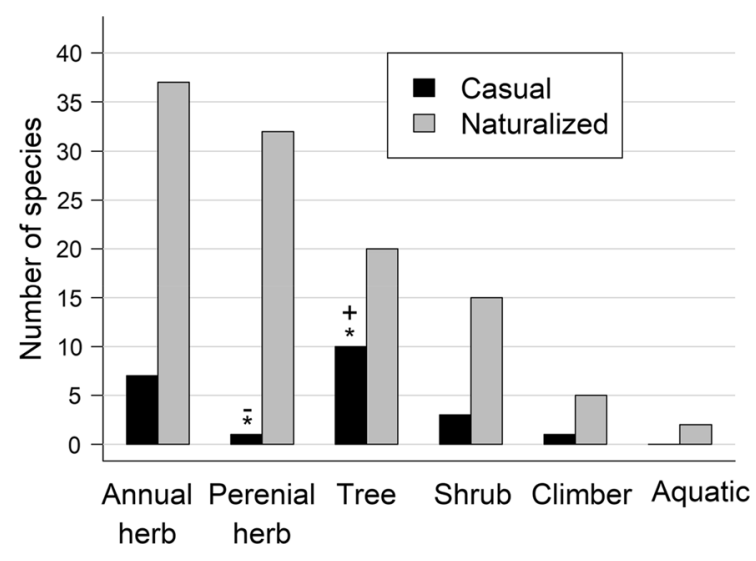

Fig. 3 Growth forms of the alien species in the Sudans according to invasion status (casual and naturalized alien species). Significant differences and their directions are indicated above the bars (-: lower than expected, + : higher than expected, *: $p<0.05)$

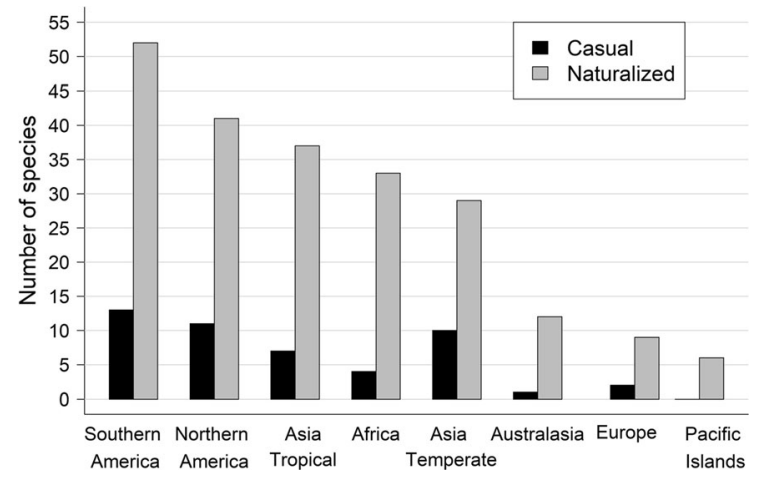

Fig. 4 Continents of origin of the alien species in the Sudans according to invasion status (casual and naturalized alien species). Continents of origin did not differ significantly in their representation among the three invasion stages. Note that the cumulative number of species in the figure exceeds the total of 113 alien species in our checklist, because some species are native to multiple continents

height, introduction history and the number of known economic uses between the two invasion-status groups (Fig. 5a-f).

\section{Discussion}

This first inventory and analysis of the alien flora of the Sudans shows that it consists of at least 113 alien species (99 in Sudan and 59 in South Sudan). The alien species represent a large number of families (44), include many annual herbs $(38.9 \%)$, and are predominantly from the Americas (85.8\%). We found that most alien species were first recorded in the mid1900s, and that now 92 of the alien species are fully naturalized. While the naturalized species distinguished themselves from the casual ones in having larger native range sizes and tend to have a wider naturalization extent, we did not find any other differences between these two invasion stages in species characteristics. The naturalized species are still mainly found in anthropogenic habitats, but almost $40 \%$ of the species are found in natural habitats such as wetlands, and forest and bushlands. These numbers might still change with more intensive research on alien plants in the Sudans, but our data provide an important first baseline.

The 92 naturalized plants in the Sudans represent $2.2 \%$ of its total flora of (4096 taxa; Darbyshire et al. 2015). This percentage is lower than those reported for 

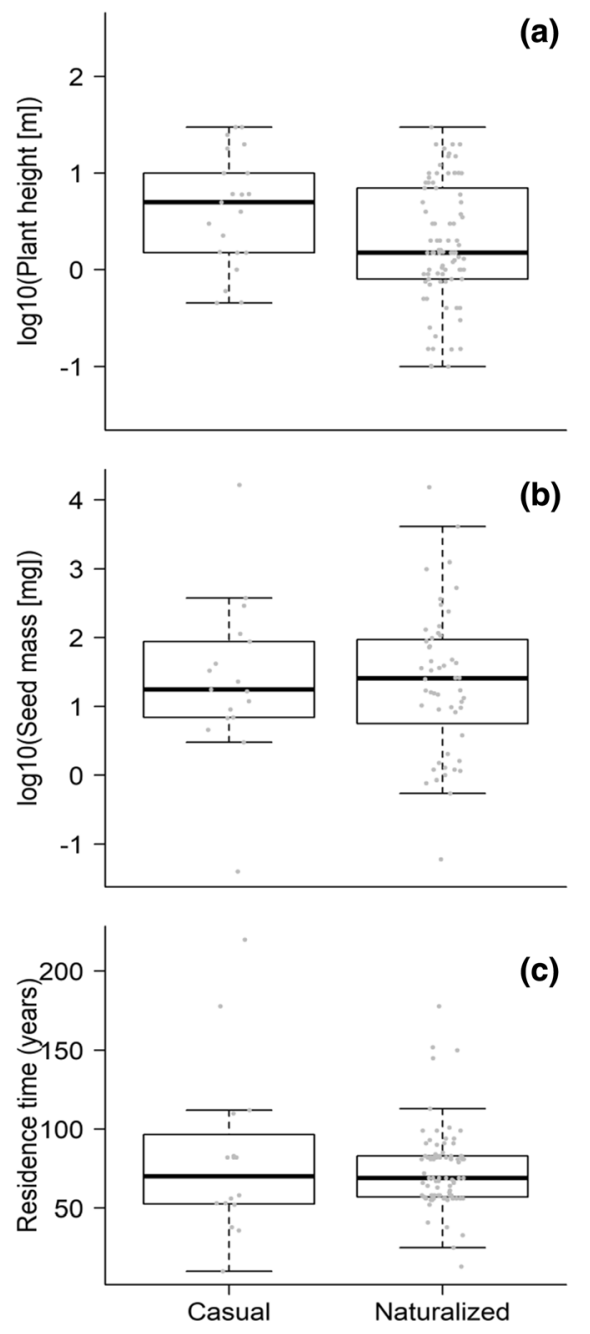

Fig. 5 Characteristics of the species in the different invasionstatus groups (casual and naturalized): plant height (a), seed mass (b), minimum residence time (c), native range size (number of TDWG-2 regions) (d), global naturalization extent (number of GloNAF regions) (e), and number of known economic uses (f). The data for each individual species are

neighboring countries with comparable climates, such as Egypt $(8.7 \%)$, Eritrea (8.5\%), Lybia $(7.5 \%)$ and Ethiopia (6\%) (Pyšek et al. 2017c). Most neighboring countries do not have data on casual species, but we recorded a lower number of casual species (21 species) for the Sudans than for Egypt (114 species; El-Beheiry et al. 2020) and Algeria (76 species; Meddour et al. 2020), although these regions are smaller than the Sudans. This might indicate that the number of casuals in our inventory is still an underestimate of the true number of casuals in the Sudans. Possibly, this is because casuals are less likely to be recorded as they
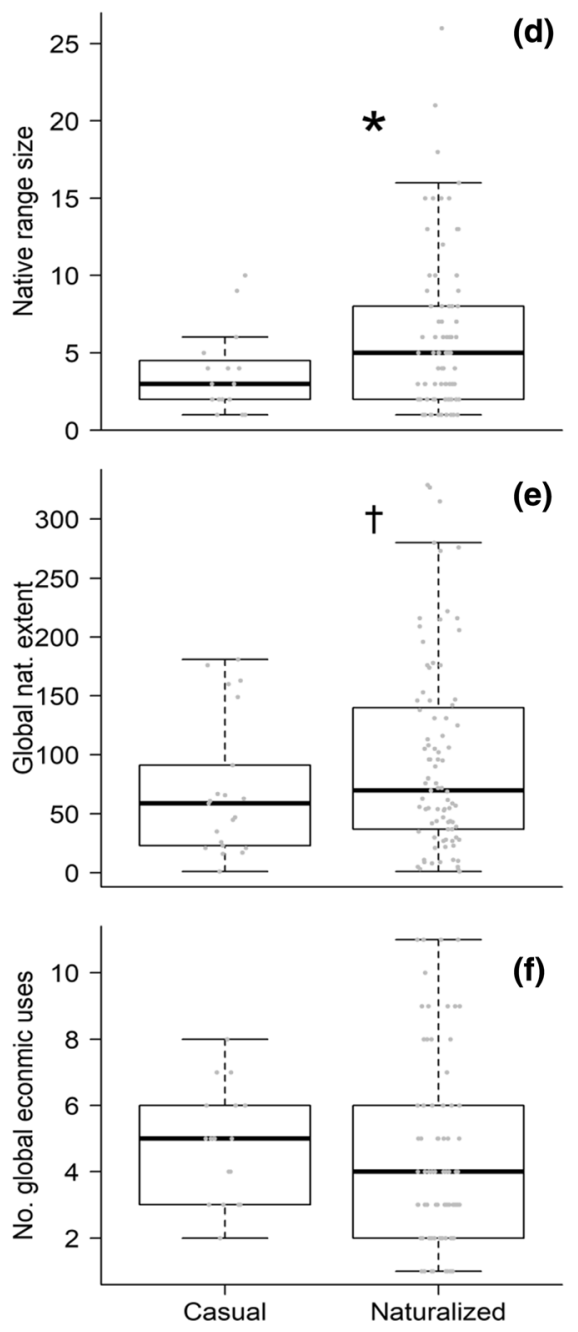

shown in grey dots. The thick horizontal line in each box indicates the median of the species characteristic, the box indicates the interquartile range, and the whiskers extend outside the box to 1.5 times the interquartile range. Asterisks indicate significant differences between the compared medians $(\dagger: p<0.1, *: p<0.05)$

are not widespread and have no major ecological or economic impacts. Overall, the recorded numbers of alien species in most African countries is very low in comparison to countries with more intensive botanical recording and biological invasion research, such as Belgium (1969 species), the United Kingdom (1779 species) and the Czech Republic (1378 species) (Lambdon et al. 2008). This suggests that alien floras in the Sudans and its neighboring countries are still under-explored.

We found that annual and perennial herbs were the prevailing life forms in the alien flora of the Sudans 
(38.9\% and $29.2 \%$, respectively). This pattern is similar to the whole native flora of the Sudans, where herbaceous species account for more than $60 \%$, and woody species for around $31 \%$ (Darbyshire et al. 2015). While perennial herbs were under-represented among the casual species, they tend to be overrepresented among the naturalized species (Fig. 3). The opposite was true for the trees (Fig. 3). This could partly reflect a biased recording of casual trees, as they are more conspicuous than herbaceous species due to their size and longevity. The overall pattern of herbaceous species being more represented in the alien flora than woody species is also consistent with the findings of other alien-flora studies in Africa (ElBeheiry et al. 2020; Meddour et al. 2020) and countries outside of Africa, such as India (Inderjit et al. 2018) and Russia (Vinogradova et al. 2018). The predominance of herbaceous alien species could partly be explained by the fact that $70 \%$ of the crops in Africa are introduced (Wood 1988). Moreover, herbaceous species might be more successful as naturalized species than the woody ones, because they can more easily establish in disturbed habitats through fast and profuse seed production (Baker 1965; Schippers et al. 2001).

Soon after the start of the Anglo-Egyptian condominium of the Sudans in 1899 (Metz 1991), the first records of alien species started to increase. This may not only reflect that the British explored the Sudanese flora, but also indicates that they played an important role in introducing alien species to the Sudans. Most alien species in the Sudans, however, are not native to Europe, but to Southern America followed by Northern America and Tropical Asia. This might reflect that the climate in Sudan is not suitable for most European plants, and that the British exchanged plants between distant regions of their colonial empire (Baber 2016). The largest donor continents of alien species overall were also the largest donors of naturalized species. This suggests that a biased introduction of species from certain regions might underlie patterns in the proportion of species from these regions in the naturalized flora (van Kleunen et al. 2020). In the global naturalized flora, Temperate Asia and Europe are the major donors (Pyšek et al. 2017b; van Kleunen et al. 2015), and this is also the case for regional temperate alien floras (e.g. (Vinogradova et al. 2018). However, other warmer regions have, just like the Sudans, many alien species from the Americas and
Tropical Asia (Ansong et al. 2019; El-Beheiry et al. 2020; Inderjit et al. 2018). This emphasizes that climate matching plays a major role in the flows of alien species around the globe.

Naturalization success in the Sudans was positively associated with native range size and global naturalization extent (although the latter was only marginally significant). This indicates that species that are native or able to adapt (i.e. naturalize) to multiple continents have a higher chance to be introduced and naturalize. This provides further evidence that native range size is positively associated with naturalization success (Goodwin et al. 1999; Maurel et al. 2016; Prinzing et al. 2002; Razanajatovo et al. 2016). However, we found no significant association of any of the other species characteristics with the two invasion-status categories (Fig. 5). Possibly, there will be some differences between invasive and non-invasive naturalized alien plants, but unfortunately data on invasiveness are still very limited for the Sudans. Furthermore, although there is variation in the total number of alien species and the number of naturalized species among the nine regions of the Sudans (Fig. 1: Map of the Sudans subdivided into nine regions following (Darbyshire et al. 2015); the northern six regions are in Sudan (NS, RS, DAR, KOR, CS and ES) and the southern three regions are in South Sudan (BAG, UN and EQU). For full names of the regions, see Table 1. Pie charts show the invasion-status composition of alien plant in each region, and their sizes are proportional to the total number of alien species in the region. and Table 1), we also found no significant association of these numbers with geographical, climatic, and socio-economic characteristics of the regions.

In conclusion, this study presents the first inventory and analysis of the alien flora of the Sudans. Since research on biological invasions in the Sudans has been very much neglected, we hope that this study will foster more research and recording of alien species, not just plants, in the Sudans. This will contribute to a better understanding of the characteristics, patterns, and consequences of biological invasions, and ultimately will allow for a better management and control. Similar studies in other regions with hitherto few data on biological invasions will contribute to improve our understanding of global invasion patterns. 


\section{Availability of data and material (data transparency)}

All data generated or analysed during this study are included in this published article and its supplementary information files.

Acknowledgements AO thanks the Ministry of Higher Education of Sudan, the University of Konstanz, and the International Max Planck Research School for Organismal Biology for funding and support. MvK acknowledges support by the German Research Foundation DFG (Grant 264740629). PP was supported by EXPRO Grant No. 19-28807X (Czech Science Foundation) and long-term research development Project RVO 67985939 (Czech Academy of Sciences).

Funding Open Access funding enabled and organized by Projekt DEAL. This study was supported by several funding agencies that could be found in the acknowledgement section.

\section{Compliance with ethical standards}

Conflicts of interest The authors have no Conflicts of interest to disclose.

Open Access This article is licensed under a Creative Commons Attribution 4.0 International License, which permits use, sharing, adaptation, distribution and reproduction in any medium or format, as long as you give appropriate credit to the original author(s) and the source, provide a link to the Creative Commons licence, and indicate if changes were made. The images or other third party material in this article are included in the article's Creative Commons licence, unless indicated otherwise in a credit line to the material. If material is not included in the article's Creative Commons licence and your intended use is not permitted by statutory regulation or exceeds the permitted use, you will need to obtain permission directly from the copyright holder. To view a copy of this licence, visit http://creativecommons.org/licenses/by/4.0/.

\section{References}

Ammar E (2020) Garden plant diversity in Nile region of Egypt and effect of climate change on its conservation and ecosystem services. Dgree Publisher, Egypt

Ansong M, Pergl J, Essl F et al (2019) Naturalized and invasive alien flora of Ghana. Biol Invasions 21:669-683

Baard JA, Kraaij T (2014) Alien flora of the garden route national park, South Africa. S Afr J Bot 94:51-63

Baber Z (2016) The plants of empire: botanic gardens, colonial power and botanical knowledge. J Contemp Asia 46:659-679

Baker HG (1965) Characteristics and modes of origin of weeds. In: Baker HG, Stebbins G (eds) The genetics of colonizing species. Academic Press Inc., New York, pp 147-172
Blackburn TM, Pysek P, Bacher S et al (2011) A proposed unified framework for biological invasions. Trends Ecol Evol 26:333-339

Cayuela L, Macarro I, Stein A, Oksanen J (2019) Taxonstand: Taxonomic Standardization of Plant Species Names R package 2.2. https://CRAN.Rproject.org/package= Taxonstand

Darbyshire I, Pickering H, Kordofani M, Farag I, Candiga R (2015) The plants of Sudan and South Sudan: an annotated checklist

Divíšek J, Chytrý M, Beckage B et al (2018) Similarity of introduced plant species to native ones facilitates naturalization, but differences enhance invasion success. Nat Commun 9:4631

El-Beheiry M, Hosni H, Sharaf El-din A, Shaltout SK, Ahmed D (2020) Updating the checklist of the alien flora in Egypt. Taeckholmia 40:41-56

Engemann K, Sandel B, Boyle B et al (2016) A plant growth form dataset for the new world. Ecology 97:3243-3243

Goodwin BJ, McAllister AJ, Fahrig L (1999) Predicting invasiveness of plant species based on biological information. Conserv Biol 13:422-426

Hamilton MA, Murray BR, Cadotte MW et al (2005) Life-history correlates of plant invasiveness at regional and continental scales. Ecol Lett 8:1066-1074

Inderjit PJ, van Kleunen M et al (2018) Naturalized alien flora of the Indian states: biogeographic patterns, taxonomic structure and drivers of species richness. Biol Invasions 20:1625-1638

Kattge J, Bönisch G, Díaz S et al (2020) TRY plant trait database-enhanced coverage and open access. Glob Change Biol 26:119-188

Khuroo AA, Reshi ZA, Malik AH et al (2012) Alien flora of India: taxonomic composition, invasion status and biogeographic affiliations. Biol Invasions 14:99-113

Lambdon P-W, Pyšek P, Basnou C et al (2008) Alien flora of Europe: species diversity, temporal trends, geographical patterns and research needs. Preslia -Praha 80:101-149

Maurel N, Hanspach J, Kuhn I, Pysek P, van Kleunen M (2016) Introduction bias affects relationships between the characteristics of ornamental alien plants and their naturalization success. Global Ecol Biogeogr 25:1500-1509

Meddour R, Sahar O, Fried G (2020) A preliminary checklist of the alien flora of Algeria (North Africa): taxonomy, traits and invasiveness potential. Bot Lett 167:453-470

Metz HC (1991) Sudan: a country study. Federal Research Division Library of Congress, Washington

Musil CF, Macdonald IAW, Germishuizen G, Du Plessis E, South African National Biodiversity I (2007) Invasive alien flora and fauna in South Africa: expertise and bibliography. South African National Biodiversity Institute, Pretoria

Nakagawa S (2015) Missing data: mechanisms, methods, and messages. In: Fox AG, Negrete-Yankelevich S, Sosa JV (eds) Ecological statistics. Contemporary theory and application. Oxford University Press, Oxford, pp 81-105

Pinto-Ledezma JN, Villalobos F, Reich PB et al (2020) Testing Darwin's naturalization conundrum based on taxonomic, phylogenetic, and functional dimensions of vascular plants. Ecol Monogr 90:e01420 
Pratt CF, Constantine KL, Murphy ST (2017) Economic impacts of invasive alien species on African smallholder livelihoods. Global Food Secur 14:31-37

Prinzing A, Durka W, Klotz S, Brandl R (2002) Which species become aliens? Evol Ecol Res 4:385-405

Pyšek P, Hulme PE, Simberloff D et al (2020) Scientists' warning on invasive alien species. Biol Rev 95:1511-1534

Pyšek P, Jarošík V (2005) Residence time determines the distribution of alien plants. In: Inderjit S (ed) Invasive plants: ecological and agricultural aspects. Birkhäuser, Basel, pp 77-96

Pyšek P, Jarošík V, Hulme PE et al (2012) A global assessment of invasive plant impacts on resident species, communities and ecosystems: the interaction of impact measures, invading species' traits and environment. Glob Change Biol 18:1725-1737

Pyšek P, Meyerson LA, Simberloff D (2017a) Introducing "Alien Floras and Faunas", a new series in biological invasions. Biol Invasions 20:1375-1376

Pyšek P, Pergl J, Essl F et al (2017b) Naturalized alien flora of the world. Preslia 89:203-274

Pyšek P, Pergl J, Essl F et al (2017c) Naturalized alien flora of the world: species diversity, taxonomic and phylogenetic patterns, geographic distribution and global hotspots of plant invasion. Preslia 89:203-274

Pyšek P, Richardson DM (2007) Traits associated with invasiveness in alien plants: where do we stand? In: Nentwig W (ed) Biol invasions. Springer, Berlin, pp 97-125

Pyšek P, Richardson DM, Pergl J et al (2008) Geographical and taxonomic biases in invasion ecology. Trends Ecol Evol 23:237-244

Pyšek P, Sádlo J, Mandák B (2002) Catalogue of alien plants of the Czech Republic Preslia. Preslia 74:97-186

R Core Team (2019) R: A Language and Environment for Statistical Computing. 3.6.1 edn. R Foundation for Statistical Computing., Vienna, Austria,

Razanajatovo M, Maurel N, Dawson W et al (2016) Plants capable of selfing are more likely to become naturalized. Nat Commun 7:13313

Rejmánek M (2000) Invasive plants: approaches and predictions. Austral Ecol 25:497-506

Rice A, Smarda P, Novosolov M et al (2019) The global biogeography of polyploid plants. Nat Ecol Evol 3:265-273

Richardson DM, Pysek P, Rejmanek M et al (2000) Naturalization and invasion of alien plants: concepts and definitions. Divers Distrib 6:93-107

Richardson DM, Witt ABR, Pergl J et al (2020) Plant invasions in Africa. In: Clements DR, Upadhyaya MK, Joshi S, Shrestha A (eds) Global plant invasions. Springer, Berlin (in press)

Schippers P, van Groenendael JM, Vleeshouwers LM, Hunt R (2001) Herbaceous plant strategies in disturbed habitats. Oikos 95:198-210
Seebens H, Bacher S, Blackburn TM et al (2021) Projecting the continental accumulation of alien species through to 2050 . Glob Change Biol 27:970-982

Seebens H, Blackburn TM, Dyer EE et al (2017) No saturation in the accumulation of alien species worldwide. Nat Commun 8:14435

Stadler J, Treier UA, Klotz S, Brandl R (2008) Exotic plant species invade diversity hot spots: the alien flora of northwestern Kenya. Ecography 23:169-176

Stekhoven DJ, Bühlmann P (2011) MissForest-non-parametric missing value imputation for mixed-type data. Bioinformatics 28:112-118

Taseski GM, Beloe CJ, Gallagher RV et al (2019) A global growth-form database for 143,616 vascular plant species. Ecology 100:e02614

van Kleunen M, Dawson W, Essl F et al (2015) Global exchange and accumulation of non-native plants. Nature 525:100-103

van Kleunen M, Dawson W, Schlaepfer D, Jeschke JM, Fischer M (2010a) Are invaders different? A conceptual framework of comparative approaches for assessing determinants of invasiveness. Ecol Lett 13:947-958

van Kleunen M, Pysek P, Dawson W et al (2019) The global naturalized Alien Flora (GloNAF) database. Ecology 100:e02542

van Kleunen M, Weber E, Fischer M (2010b) A meta-analysis of trait differences between invasive and non-invasive plant species. Ecol Lett 13:235-245

van Kleunen M, Xu X, Yang Q et al (2020) Economic use of plants is key to their naturalization success. Nat Commun 11:3201

van Wilgen BW, Measey J, Richardson DM, Wilson JR, Zengeya TA (2020) Biological invasions in South Africa: an overview. In: van Wilgen BW, Measey J, Richardson DM, Wilson JR, Zengeya TA (eds) Biological invasions in South Africa. Springer, Berlin, pp 3-31

Vilà M, Hulme PE (2017) Non-native species, ecosystem services, and human well-being. In: Vilà M, Hulme PE (eds) Impact of biological invasions on ecosystem services. Springer, Cham, pp 1-14

Vinogradova Y, Pergl J, Essl F et al (2018) Invasive alien plants of Russia: insights from regional inventories. Biol Invasions 20:1931-1943

WCSP (2015) World checklist of selected plant families. In. http://apps.kew.org/wcsp/. Accessed: 2015

Wood D (1988) Introduced crops in developing countries. Food Policy 13:167-177

Publisher's Note Springer Nature remains neutral with regard to jurisdictional claims in published maps and institutional affiliations. 